Article

\title{
Empirical Evidence Regarding the Impact of Economic Growth and Inflation on Economic Sentiment and Household Consumption
}

\author{
Larissa Batrancea (1C)
}

check for updates

Citation: Batrancea, Larissa. 2021. Empirical Evidence Regarding the Impact of Economic Growth and Inflation on Economic Sentiment and Household Consumption. Journal of Risk and Financial Management 14: 336. https://doi.org/10.3390/ jrfm14070336

Academic Editors:

Irena Jindřichovská,

Anna Białek-Jaworska,

Mihaela Mocanu and

Erginbay Uğurlu

Received: 13 June 2021

Accepted: 16 July 2021

Published: 20 July 2021

Publisher's Note: MDPI stays neutral with regard to jurisdictional claims in published maps and institutional affiliations.

Copyright: (c) 2021 by the author Licensee MDPI, Basel, Switzerland. This article is an open access article distributed under the terms and conditions of the Creative Commons Attribution (CC BY) license (https:// creativecommons.org/licenses/by/ $4.0 /)$
Faculty of Business, Babes-Bolyai University, 400174 Cluj-Napoca, Romania; larissa.batrancea@ubbcluj.ro

\begin{abstract}
The dynamics of the interconnected global market and consumption behavior has recently changed considerably. Using a sample of 28 nations within the European Union, the study examined the degree to which economic growth and inflation impacted economic sentiment and household consumption during the time frame of December 2019 up to October 2020. The results estimated via panel generalized method of moments and panel least squares (with cross-section weights, time fixed effects) showed that economic sentiment and household consumption were significantly shaped by the proxies of economic growth and inflation. Moreover, in the case of economic sentiment, the negative impact of inflation was much stronger than the positive impact of economic growth. The reverse applied in the case of household consumption. The study draws policy implications regarding the strategies that public authorities, companies, and individual consumers could apply for stimulating national economies amid challenging times.
\end{abstract}

Keywords: economic sentiment; household consumption; economic growth; inflation; unemployment

\section{Introduction}

Economic markets and economic activities in general entail a multitude of risks deriving from macroeconomic and microeconomic factors, but also from political and social contexts (e.g., Bammer and Smithson 2009; Economist Intelligence Unit 2018; Funston and Wagner 2010; Köhn 2017). This statement suits nowadays' reality more than ever, considering that economic markets around the world are constantly connected, thus risks tend to propagate rapidly from one end of the globe to the other end. Moreover, when uncertainty and psychological factors come into play, individuals' behaviors and the evolution of the market change- - they become even less predictable (Baddeley 2017; Corr and Plagnol 2018; Thaler 2016) and economic sentiments favor negativity.

As defined in the literature (Nowzohour and Stracca 2020, p. 691), the concept of economic sentiment encompasses "economic agents' views of future economic developments that may drive the economy because they influence agents' decisions today, a view that may reflect rational arguments and facts but also a mood of optimism or pessimism".

Considering the unparalleled changes registered by worldwide economies in terms of consumption decisions throughout the last months starting with the end of 2019 and the onset of the global health crisis (i.e., December 2019 to October 2020), a research study on the macroeconomic variables driving household consumption and perceptions of market evolution captured via economic sentiment seemed propitious. The majority of research studies in the literature consider economic sentiment and household consumption as regular predictors when examining various macroeconomic phenomena. By focusing on these particular dependent variables, this study closes the gap in the literature and suggests certain strategies that public authorities, companies, and individual consumers could apply while trying to stimulate national economies amid challenging times.

A country sample including the 28 nations within the European Union was considered for the purpose of this study, that is: Austria, Belgium, Bulgaria, Croatia, Cyprus, Czech Republic, Denmark, Estonia, Finland, France, Germany, Greece, Hungary, Ireland, Italy, 
Latvia, Lithuania, Luxembourg, Malta, The Netherlands, Poland, Portugal, Romania, Slovenia, Slovakia, Spain, Sweden, and United Kingdom. This particular sample was chosen because countries within the European Union were among the first to register changes in consumption patterns and economic sentiment on the grounds of the current health crisis. The outcome variables were measured via the economic sentiment indicator and final consumption expenditure of households. Economic growth was proxied by gross domestic product, while inflation was proxied by two harmonized indices of consumer prices. Moreover, wages and salaries along with total unemployment rate were used as control variables. All data covering the period of December 2019 to October 2020 were retrieved from the Eurostat database.

By means of economic modelling conducted via the panel generalized method of moments and panel least squares with cross-section weights, robust evidence indicated that the macroeconomic variables taken into consideration influenced the general economic sentiment and the consumption pattern of European households to a great extent. Therefore, the study broadens the extant literature delving into economic sentiment and household consumption.

The structure of this article is as follows: Section 2 surveys recent literature regarding economic sentiment and household consumption. Section 3 describes the independent and dependent variables, sample, time frame, announces the research hypotheses, and the general econometric model. Results are presented and discussed in Section 4. Section 5 draws on concluding remarks, study limitations, policy implications, and future research directions.

\section{Literature Review}

Dan Ariely (2010a, 2010b, 2016), a prominent researcher in behavioral economics, delves into the psychological factors that drive economic decision-making throughout people's professional and personal lives. In his studies, he builds a strong case for why people should pay more heed to psychological biases that determine them to act irrationally in many situations and how to amend decisions. For that matter, in one of his most recent books titled Dollars and Sense (Ariely and Kreisler 2017), Ariely explains some of the most common reasons behind poor management of personal finances and unsustainable consumption patterns in current societies.

As behavioral economists point out, rationality and human psychology are often intertwined when it comes to deciding on an economic outcome. Since many times perceptions, emotions, feelings, and motivations emerge while trying to make sensible decisions, psychological factors should not be disregarded but investigated to a greater extent (Batrancea and Nichita 2015; Batrancea et al. 2018; Nichita et al. 2019). This is one of the reasons for which the paper focuses on analyzing economic sentiments across members of the European Union.

The extant literature reports studies tackling psychology-driven concepts such as economic sentiment and related notions (e.g., business sentiment, consumer sentiment, or consumer confidence). Within this specific literature, a vast majority of studies are dedicated to a narrower version of economic sentiment, namely investor sentiment, which is studied mostly in connection with stock market anomalies and stock market returns. In the opinion of Baker and Wurgler (2007, p. 129), investor sentiment can be regarded as a "belief about future cash flow and investment risk that is not justified by the facts at hand". Theoretical and empirical studies are focused on different bottom-up and top-down approaches towards measuring investor sentiment via composite indices, for either crosssectional or longitudinal data (Baker and Wurgler 2006; Baker et al. 2012; Çepni et al. 2020; Pandey and Sehgal 2019; Ruan et al. 2020; Sibley et al. 2016). Nevertheless, according to Aggarwal (2019), who conducted a literature review on 81 scientific sources, studies that define and measure market sentiments provide mixed results due to various proxies used to construct sentiment indices. 
Chen et al. (2010) advanced an innovative index that was able to identify periods of high, medium, and low returns across stock market regimes. Huang et al. (2015) proposed an investor sentiment index that was able to forecast cross-sectional stock returns and ca-tegorize them by industry, momentum, size, and value, thus surpassing the efficiency of existing indices. Using data for the period 1999-2009 retrieved from the South African stock market, Dalika and Seetharam (2015) constructed an index showing that sentiments exerted a strong impact on market returns. With a specific focus on the US economy du-ring the period 1981Q3-2011Q1, Milani (2017) investigated the degree to which sentiment shocks connected to future investment decisions yielded fluctuations in the US business cycle. His empirical results indicated that changes in investors' sentiments explained more than $40 \%$ of the output fluctuation.

Recent studies have also reported notable insights. For instance, based on 45-year long data retrieved from 362 companies across 16 European countries, Nogueira Reis and Pinho (2020) showed that monthly stock returns were significantly predicted by 13 investor sentiment indices. At the other side of the spectrum, Haritha and Rishad (2020) designed an irrational sentiment index using monthly stock market data and showed that the index triggered high market volatility. With a specific focus on the German society, Rakovská (2021) designed a composite sentiment indicator that proved to be more accurate in anticipating short-term stock market performance than the standard consumer confidence indicator.

Investor sentiment was studied also in connection with mass-media influences (Sun et al. 2021). Aguilar et al. (2021) proposed a novel newspaper-based sentiment indicator in order to monitor real-time changes within the Spanish economy. The results showed that the efficiency of the new indicator in forecasting GDP evolution was superior to that of the economic sentiment indicator measured by the European Commission. Moreover, according to a study of Yang et al. (2017), investors' sentiments can be shaped and directed by the financial information they receive through mass media channels. Interestingly enough and in accordance with behavioral economics insights, the authors noticed an asymmetric influence of mass media. Namely, for bull markets (i.e., with rising prices and overconfidence), investors tend to make decisions based on favorable financial reports while disregarding negative headlines. In the case of bear markets (i.e., with plunging prices and pessimism), investors tend to decide based on negative financial reports while disregarding positive headlines.

Regarding the aforementioned concepts related to economic sentiment, the literature notes valuable insights. Van Giesen and Pieters (2019) studied the bidirectional relationship between consumer sentiment and stress level during the period 2012-2014 following the global financial crisis. The authors concluded that the more positive consumers were, the less stress they incurred. In addition, consumers experiencing higher levels of stress after the crisis were more likely to have negative sentiments regarding the economy status. Zaremba et al. (2020) examined the impact of business sentiment on equity returns and noticed that high-sentiment markets registered higher returns, as compared to lowsentiment markets. Ahmed (2020) analyzed the degree to which business and consumer sentiment indicators impacted on stock market performance of developed and emerging markets in the short and long run. Empirical evidence showed interesting results: both types of sentiments had a stronger impact on emerging markets; the positive effect of business sentiment was spread across both time horizons only in the case of developed markets and consumer sentiment positively influenced short-term returns of both markets.

Few studies have been conducted on different types of sentiments outside the stock market realm, including economic sentiment. For instance, Zanin (2010) investigated the connection between the economic sentiment indicator and real GDP on a sample of six European countries (Austria, Denmark, Estonia, Finland, France, and Italy) for the period of 1985-2008. He noticed that the variance in economic sentiment did not always generate a change in GDP. Kitrar and Lipkind (2020) investigated the relationship between a composite economic sentiment index and GDP growth in Russia for the period 1998- 
2020. The authors found that the proposed index strongly predicted the evolution of GDP. Similarly, in strict connection to the COVID-19 pandemic, Van der Wielen and Barrios (2020) analyzed household economic sentiment across Europe based on internet searches. The results showed that economic sentiment turned negative in countries most affected by the pandemic. As a side note, they concluded that measures enacted by authorities at the onset of the pandemic did not manage to improve citizens' views and beliefs regarding the future of the national economy.

With respect to household consumption, the literature also provides important insights. For instance, by using data from the Indian economy during the period 1951-2015, Swamy (2020) investigated the impact of financial assets wealth proxied via stock market capitalization on the final consumption expenditure of households. The empirical results showed a positive relationship between the variables of interest. Moreover, after analyzing data from European countries for the period 2000-2016, Telega and Telega (2020) found that per capita domestic material consumption was positively influenced by income measured via GDP per capita.

\section{Materials and Methods}

The following paragraphs will detail the sample, variables of interest, and selected time frame used in the econometric analyses.

For the purpose of this study, the following dependent variables were considered:

- Economic sentiment indicator (ESI): The composite indicator builds on answers retrieved from qualitative surveys conducted on corporate and individual consumers within the European Union ${ }^{1}$. Corporate consumers are surveyed with respect to the overall business conditions (i.e., output, inventory, orders, consumer networks). Individual consumers are surveyed with respect to their personal finance, employment status, savings opportunities and the overall economy. In other words, ESI represents an assessment of how the economic market is perceived by economic agents. Values exceeding the 100 threshold express economic sentiments above the average. Conversely, lower values of the indicator show that consumers and businesses perceive a deterioration of the overall economy;

- Final consumption expenditure of households (FCEH): The indicator comprises the overall domestic expenditure on goods and services incurred by households across the European Union (e.g., food and non-alcoholic beverages, housing and related costs, clothing, restaurants and hotels, recreation and cultural services, etc.).

In the category of predictors, the following variables were included:

- Real gross domestic product growth rate (GDP), measuring the growth rate of the overall value of all goods and services produced in an economy for consumption. The indicator is generally used in the literature to measure economic growth;

- Harmonized index of consumer prices: processed food, alcohol and tobacco (HICPF). The index measures the price shifts of perishable goods acquired at the household level;

- Harmonized index of consumer prices: restaurants, cafes, and similar (HICPH). The index measures the price shifts of ready-made food and drinks provided on the market;

- Wages and salaries (WS), capturing labor compensation. The indicator is calculated as a percentage change in comparison to the same period of the previous year. It serves as a control variable;

- Total unemployment rate (UR), indicating the unemployed labor force in a country du-ring a year that actively searches for a job. The indicator is calculated as a ratio of unemployed individuals to the overall active population in a country. It serves as a control variable.

The two harmonized indices can be regarded as proxies for inflation since they are used to facilitate comparisons between countries in terms of consumer price inflation. All variables of interest were retrieved from the Eurostat database. 
The country sample included 28 countries within the European Union (EU) for which data were available on Eurostat, namely: Austria, Belgium, Bulgaria, Croatia, Cyprus, Czech Republic, Denmark, Estonia, Finland, France, Germany, Greece, Hungary, Ireland, Italy, Latvia, Lithuania, Luxembourg, Malta, The Netherlands, Poland, Portugal, Romania, Slovenia, Slovakia, Spain, Sweden, United Kingdom.

In order to investigate how economic growth and inflation influenced economic sentiment and household consumption, a time frame of almost one year covering December 2019 to October 2020 (using monthly data) was chosen.

\section{Results}

In line with the purpose of the study, two research hypotheses were formulated:

Hypothesis 1 (H1). There is a significant relationship between ESI and GDP, HICPF, HICPH, WS, and UR.

Hypothesis 2 (H2). There is a significant relationship between FCEH and GDP, HICPF, HICPH, WS, and UR.

The econometric model had the general form below:

$$
Z_{i t}=a_{0}+a_{1} A_{1 i t}+a_{2} A_{2 i t}+a_{3} A_{3 i t}+a_{4} A_{4 i t}+a_{5} A_{5 i t}+\delta_{i}+\varepsilon_{i t}
$$

where,

- $\quad \mathrm{Z}$ denotes the dependent variables ESI and FCEH;

- $a_{0}$ denotes the intercept;

- $a_{i}$ denotes the coefficient of the independent variable;

- $\quad$ A denotes the independent variables GDP, HICPF, HICPH, WS and UR;

- $i$ denotes the country;

- $t$ denotes the time span considered;

- $\delta_{i}$ denotes the fixed effects controlling for country-specific factors, irrespective of the time;

- $\varepsilon_{i t}$ denotes the error term.

In terms of the statistical software, EViews version 9.0 was selected to examine the relationships between the variables of interest. The modelling methods used were panel two-stage least squares with cross-section weights for fixed effects estimations and panel generalized method of moments (GMM).

In order to obtain robust econometric results, a multimodal approach consisting of both descriptive statistics and inferential statistics was used. In the first place, the focus was on examining the characteristics of the data via descriptive statistics and correlation analysis. The following paragraphs offer details in this regard.

\subsection{Analysis of Central Tendency and Variation}

Table 1 provides details on the mean, median, and standard deviation for the dependent and independent variables considered across the European countries. Based on the standard deviation values, the largest volatility values were registered by the economic sentiment indicator and final consumption expenditure household, while the smallest was registered by total unemployment rate followed by wages and salaries. Skewness values indicated that five of the variables were skewed to the right and the other two were skewed to the left. Since the kurtosis values of four variables exceeded the threshold of 3, it was concluded that the distributions of these data were leptokurtic. The distributions of ESI, $F C E H$, and GDP were platykurtic since their kurtosis values were below 3. In addition, the Jarque-Bera test showed that six of the variables were non-normally distributed at the $1 \%$ and $5 \%$ levels of significance, while one variable was normally distributed. 
Table 1. Descriptive statistics for the variables of interest.

\begin{tabular}{cccccccc}
\hline & ESI & FCEH & GDP & HICPF & HICPH & UR & WS \\
\hline Mean & 87.2681 & 0.6145 & -0.1189 & 109.2330 & 112.6710 & 6.5939 & 2.9703 \\
Median & 88.8000 & -0.7000 & -0.2000 & 109.6150 & 111.8850 & 5.9500 & 3.0000 \\
Maximum & 113.9000 & 22.7000 & 18.7000 & 122.9300 & 129.9600 & 16.8000 & 40.6000 \\
Minimum & 46.9000 & -23.7000 & -19.8000 & 92.0000 & 91.9600 & 2.0000 & -19.0000 \\
Standard deviation & 13.7932 & 11.1402 & 8.7482 & 5.7349 & 6.5509 & 3.2105 & 5.9427 \\
Skewness & -0.4945 & 0.1873 & 0.0057 & -0.4867 & 0.4453 & 1.6065 & 0.2498 \\
Kurtosis & 2.7173 & 2.3086 & 2.4453 & 3.7173 & 3.8583 & 5.6965 & 10.1815 \\
Jarque-Bera test & $13.5329 * * *$ & $7.4706 * *$ & 3.8100 & $18.7605 * * *$ & $19.6301 * * *$ & $217.00322^{* * *}$ & $602.4501^{* * *}$ \\
Probability & 0.0012 & 0.0239 & 0.1488 & 0.0001 & 0.0001 & 0.0000 & 0.0000 \\
Observations & 307 & 290 & 297 & 308 & 308 & 296 & 279 \\
\hline
\end{tabular}

Note: The symbols ${ }^{* * *}$ and ${ }^{* *}$ indicate significance at the $1 \%$ and $5 \%$ levels.

The evolution of the dependent variables ESI and FCEH (see Figures 1 and 2) and the independent variables (Figures 3-6) across the selected time frame was also inspected. Figure 1 displays a significant mitigation in the economic sentiment indicator starting with the third month of 2020 across all countries. The biggest drops were registered by Poland, Malta, Slovakia, and Denmark.

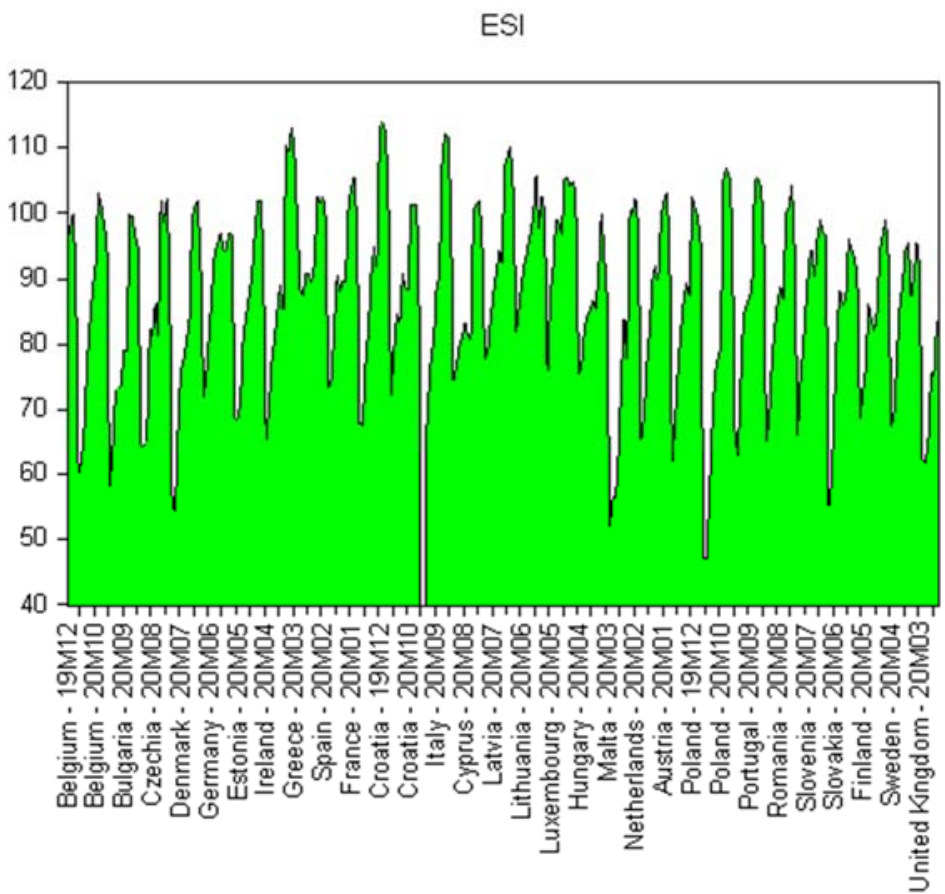

Figure 1. Evolution of the economic sentiment indicator (ESI) across the country sample. Note: Fi-gures displayed after the symbol $\mathrm{M}$ indicate the number of the month in the calendar year.

According to Figure 2, the final consumption expenditure of households displayed a decreasing trend starting especially with the first quarter of 2020. In this case, United Kingdom (2020M03), Ireland (2020M04), Spain (2020M02), Cyprus (2020M08), Malta (2020M03), and Portugal (2020M09) were among the countries with the biggest declines.

Figure 3 shows that the biggest increases GDP wise were registered by countries such as Croatia, Italy, France, United Kingdom, and Ireland.

Figure 4 indicates that the highest levels of inflation were reached by economies from Lithuania, Hungary, Malta, the Netherlands, and Bulgaria. 
FCEH

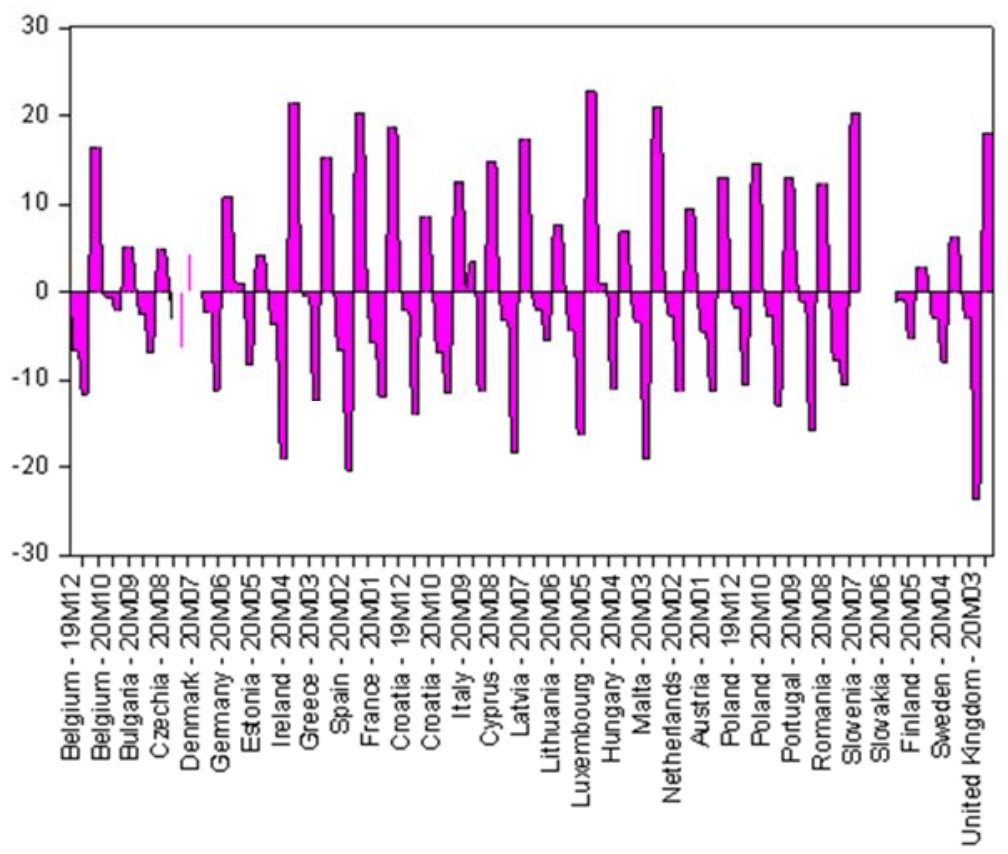

Figure 2. Evolution of the final consumption expenditure for households (FCEH) across the country sample. Note: Figures displayed after the symbol $\mathrm{M}$ indicate the number of the month in the calendar year.

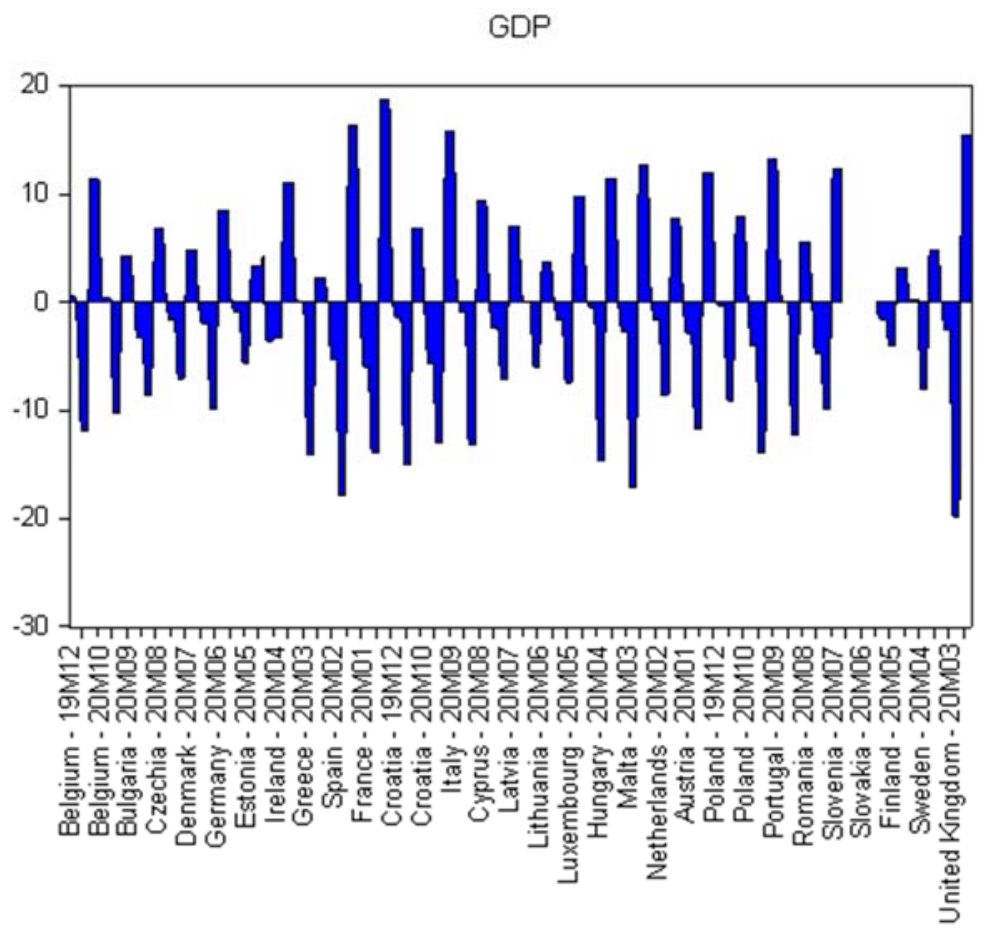

Figure 3. Evolution of the real gross domestic product growth rate (GDP) across the country sample. Note: Figures displayed after the symbol M indicate the number of the month in the calendar year. 


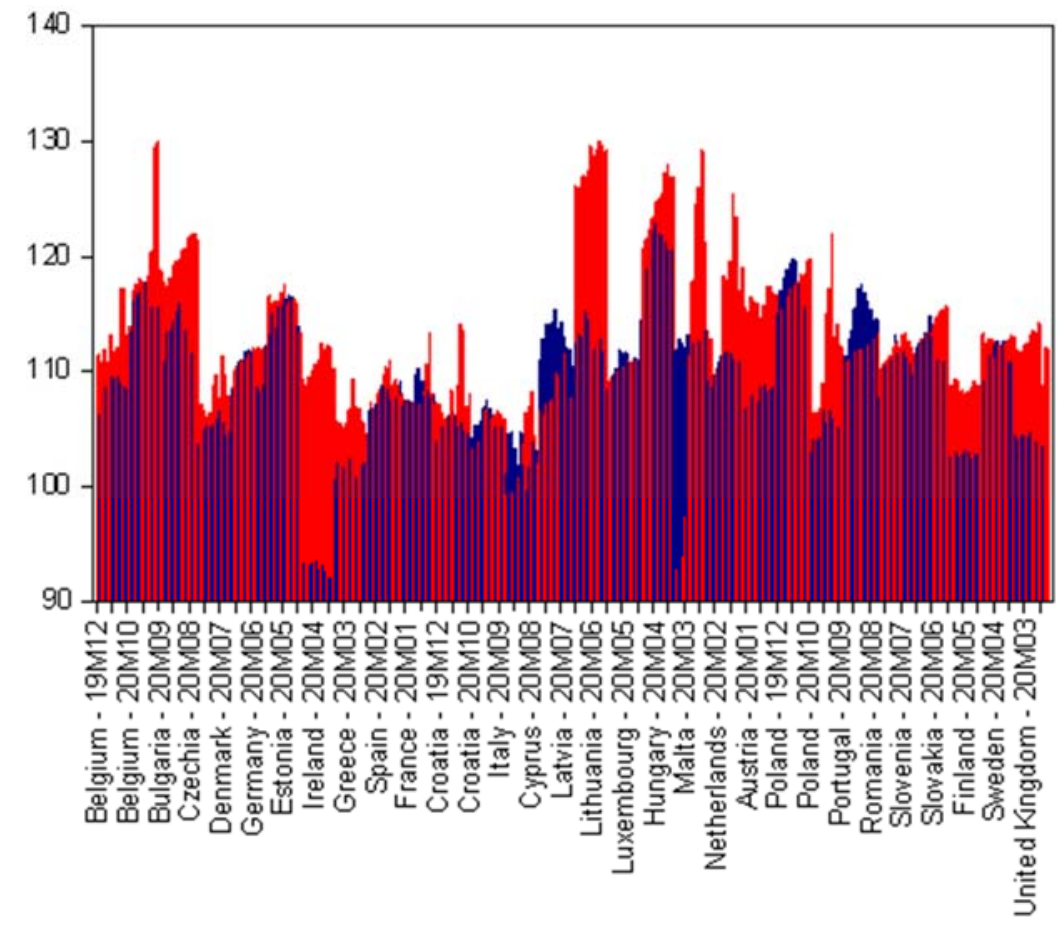

HICPF $\square \mathrm{HICPH}$

Figure 4. Evolution of harmonized indices of consumer prices (HICPF, HICPH) across the country sample. Note: Figures displayed after the symbol $\mathrm{M}$ indicate the number of the month in the calendar year.

UR

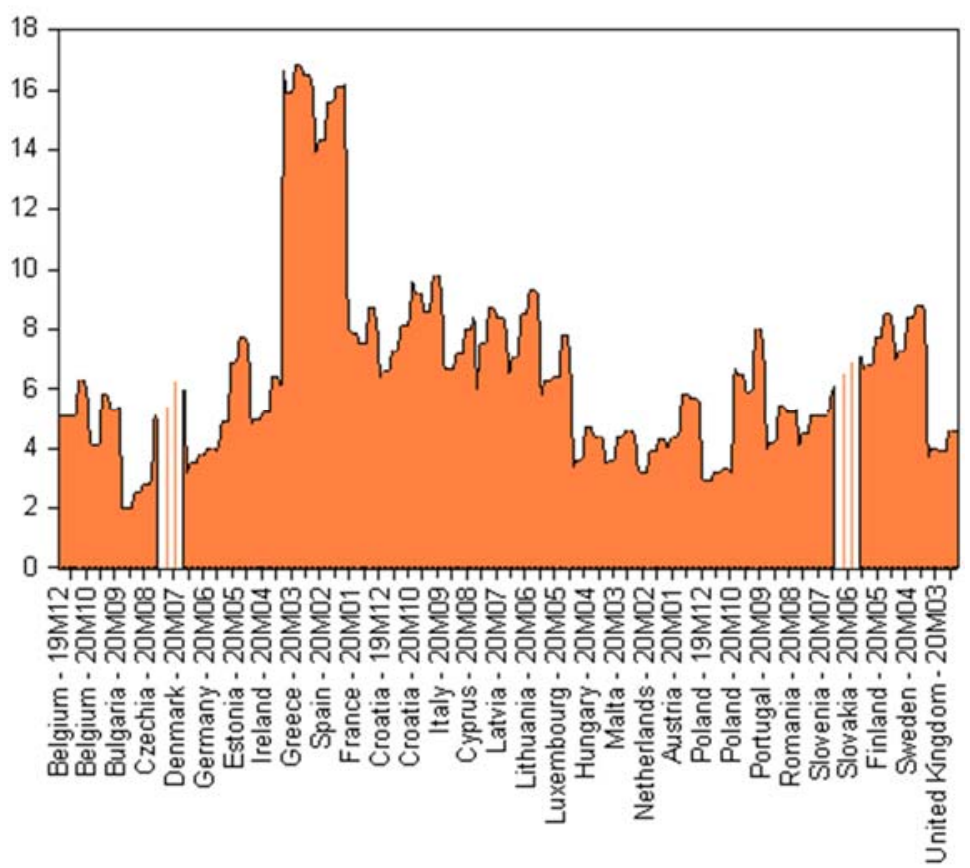

Figure 5. Evolution of total unemployment rate $(U R)$ across the country sample. Note: Figures displayed after the symbol $\mathrm{M}$ indicate the number of the month in the calendar year. 
WS

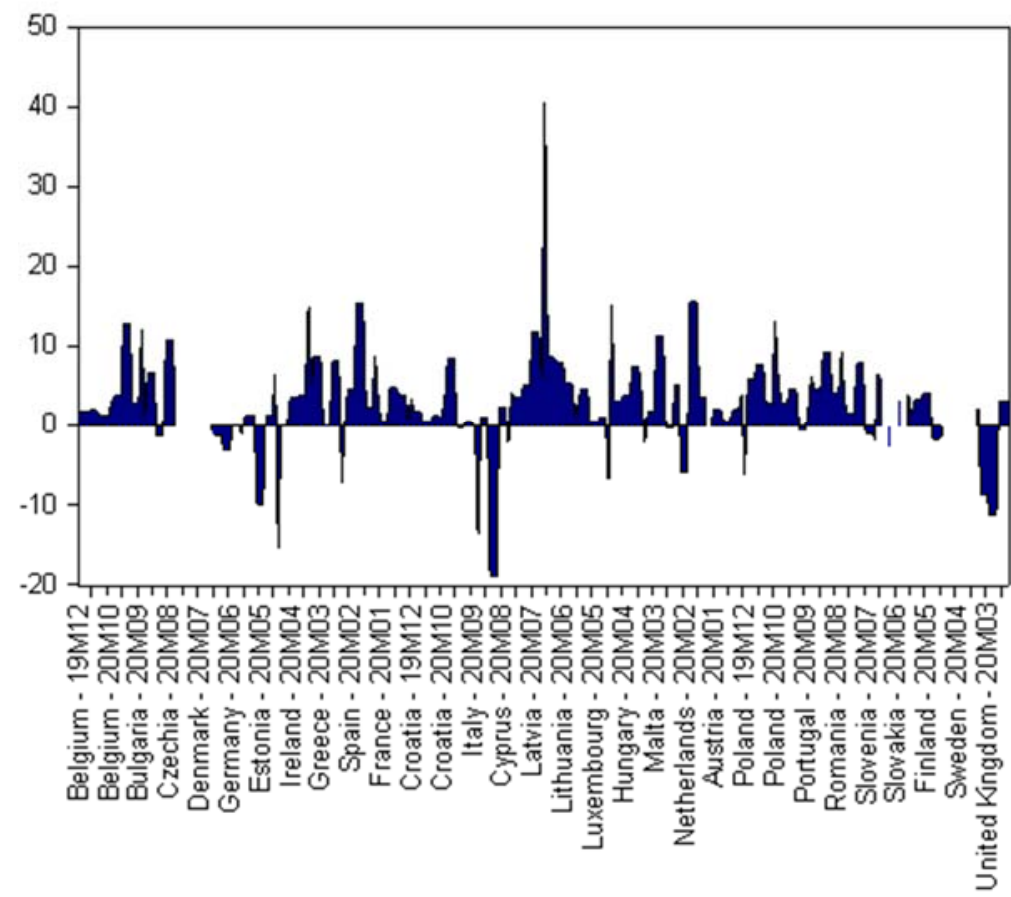

Figure 6. Evolution of wages and salaries (WS) across the country sample. Note: Figures displayed after the symbol $\mathrm{M}$ indicate the number of the month in the calendar year.

With respect to the evolution of the control variables UR and WS, Figure 5 showed that the biggest number of unemployed people was registered in countries such as Greece, Spain, Italy, Lithuania, and Portugal. According to Figure 6, the largest drops in the levels of wages and salaries were reported in Italy, Cyprus, Estonia, Greece, and the United Kingdom.

\subsection{Analysis of Correlation}

Before applying econometric modeling to the data, it was necessary to control for possible multicollinearity issues between the five predictors. Hence, the Pearson's correlation coefficients via correlation analysis were computed.

The results in Table 2 indicated that the highest correlation of two predictors was registered between HICPF and HICPH $(r=0.53)$. Since none of the correlation coefficients were above 0.75 between the independent variables, it was concluded that multicollinea-rity would pose no problem for the econometric estimations.

Table 2. Correlation matrix for the variables of interest.

\begin{tabular}{|c|c|c|c|c|c|c|c|}
\hline & $E S I$ & FCEH & GDP & HICPF & НІСРН & UR & WS \\
\hline ESI & 1 & & & & & & \\
\hline FCEH & $0.265^{*}$ & 1 & & & & & \\
\hline GDP & $0.306^{*}$ & $0.927^{* * *}$ & 1 & & & & \\
\hline HICPF & -0.166 & -0.069 & -0.088 & 1 & & & \\
\hline НІСРН & -0.229 & 0.056 & 0.063 & 0.532 ** & 1 & & \\
\hline UR & 0.151 & 0.089 & 0.034 & -0.355 & -0.340 * & 1 & \\
\hline WS & -0.021 & 0.011 & 0.003 & 0.248 & 0.276 & 0.107 & 1 \\
\hline
\end{tabular}




\subsection{Econometric Models}

The Hausman test was applied with the purpose of choosing between cross-section fixed and random effects panel-data modeling. Regarding the Hausman test, should the null hypothesis be accepted, the cross-section random effects model is recommended. Contrariwise, the cross-section fixed effects model should be used. In the case of the eco-nometric models examining the determinants of economic sentiment and household consumption, because the $p$-value corresponding to the Hausman test registered a value below 0.05 , the null hypothesis was rejected and fixed effects were incorporated into the analysis. The relationships were tested in the presence and absence of time fixed effects.

With the purpose of controlling for endogeneity issues, the panel two-stage least squares method for fixed-effects models was used. Moreover, the panel generalized method of moments (GMM) was also employed, which eliminates issues related to heteroscedasticity and endogeneity. The GMM method entails multiple benefits since it: (1) takes into account the time and cross-sectional dimensions of empirical data; (2) takes into account country fixed effects; (3) controls for predictors' endogeneity.

Table 3 contains the results of the econometric analysis. The first econometric model (M1) conducted with panel GMM indicated that, except for WS, all the independent variables reached significance and explained $10.12 \%$ of the variance in economic sentiment. Namely, when GDP augmented by one unit, ESI would follow the same trend with 1.08 units. At the same time, if HICPF increased by one unit, economic sentiment would decrease by 2.83 units, as expected. Also, if HICPH augmented by one unit, economic sentiment would decrease by 0.91 units. Finally, if $U R$ followed an increasing trend, economic sentiment would decrease at least by 20.56 units, which is quite a substantial mitigation.

According to the second econometric model (M2), which did not account for time fixed effects and was run with the panel least squares method, the independent variables explained $54.21 \%$ of the variance in the economic sentiment indicator $(F=6.56, p<0.001)$. While GDP had a positive influence on the dependent variable, the two harmonized indices of consumer prices and total unemployment established a negative relationship with economic sentiment. Namely, if GDP increased by one unit, ESI would augment by 0.55 units. On the other hand, should HICPF, HICPH, and UR rise by one unit, the economic sentiment indicator would register a reduction of 5.28 units, 1.06 units, and 6.61 units, respectively. As can be seen, the impact of the harmonized indices was much stronger (i.e., decreases of at least $52 \%$ ) than the impact of GDP. At the same time, the control va-riable total unemployment rate had the strongest effect of all predictors.

The third econometric model (M3), which took account for the time fixed effects, showed that the independent variables explained $88.42 \%$ of the variance in the economic sentiment indicator $(F=56.62, p<0.001)$. While GDP and $U R$ had a positive influence on the dependent variable, HICPH established a negative relationship with the economic sentiment indicator. Namely, if GDP and UR increased by one unit, ESI would augment by 0.39 units and 3.44 units. On the other hand, should HICPH rise by one unit, the economic sentiment indicator would register a reduction of 0.27 units. This time, the impact of GDP was much stronger than the impact of HICPH. Again, the total unemployment rate exerted the biggest influence on the evolution of ESI.

Based on these three models (M1-M3), it can be stated that the first research hypothesis was supported.

With respect to the estimations elicited by the first three econometric models, I deem that the negative impact of harmonized price indices on the economic sentiment indicator (which measures perceptions) could be explained under the framework of "prospect theory" (Kahneman and Tversky 1979; Kahneman 2012; Wakker 2010). According to this theory widely encountered in behavioral economics, individuals perceive gains and losses in a distinct manner, with losses triggering much more emotional impact than gains. In the analyzed time frame, as soon as prices of basic goods and services started to increase while resources became less accessible, consumers' income levels mitigated. Consequently, 
individuals' income losses translated into a negative perception of the personal financial state, job opportunities, overall economy and future savings possibilities.

Table 3. Econometric models estimating the relationships between the variables of interest.

\begin{tabular}{|c|c|c|c|c|c|c|}
\hline & \multicolumn{3}{|c|}{$\begin{array}{c}\text { Model ESI } \\
E S I=a_{0}+a_{1} G D P+a_{2} H I P C F+a_{3} H I P C H+ \\
a_{4} W S+a_{5} U R+\delta_{i}+\varepsilon_{i t}\end{array}$} & \multicolumn{3}{|c|}{$\begin{array}{c}\text { Model FCEH } \\
F C E H=a_{0}+a_{1} G D P+a_{2} H I P C F+a_{3} H I P C H+ \\
a_{4} W S+a_{5} U R+\delta_{i}+\varepsilon_{i t}\end{array}$} \\
\hline & M1 & M2 & M3 & M4 & M5 & M6 \\
\hline Constant & $\begin{array}{c}141.9588^{* * *} \\
(6.3440)\end{array}$ & $\begin{array}{c}828.1558^{* * *} \\
(6.1997)\end{array}$ & $\begin{array}{l}128.5147 \\
(1.5582)\end{array}$ & $\begin{array}{l}-10.5989 \\
(-1.3709)\end{array}$ & $\begin{array}{c}0.1016 \\
(0.0032)\end{array}$ & $\begin{array}{l}-35.474 \\
(-0.9127)\end{array}$ \\
\hline GDP & $\begin{array}{l}1.0791 * * * \\
(13.5722)\end{array}$ & $\begin{array}{l}0.5469 * * * \\
3.3298\end{array}$ & $\begin{array}{l}0.3938^{* * *} \\
(2.6408)\end{array}$ & $\begin{array}{l}1.2977^{* * *} \\
(22.4175)\end{array}$ & $\begin{array}{l}1.1403 * * * \\
(46.6969)\end{array}$ & $\begin{array}{l}0.7784^{* * *} \\
(11.4189)\end{array}$ \\
\hline HICPF & $\begin{array}{l}-2.8270 * * * \\
(-7.3420)\end{array}$ & $\begin{array}{l}-5.2783^{* * *} \\
(-4.2129)\end{array}$ & $\begin{array}{l}-0.3054 \\
(-0.3952)\end{array}$ & $\begin{array}{l}0.6931^{* * *} \\
(4.1739)\end{array}$ & $\begin{array}{c}-0.1641 \\
(-0.5147)\end{array}$ & $\begin{array}{c}0.3806 \\
(0.9962)\end{array}$ \\
\hline $\mathrm{HICPH}$ & $\begin{array}{l}-0.9076^{* * *} \\
(-4.5289)\end{array}$ & $\begin{array}{l}-1.0561 * * * \\
(-3.9561)\end{array}$ & $\begin{array}{l}-0.2718^{* *} \\
(-2.1437)\end{array}$ & $\begin{array}{c}-0.0024 \\
(-0.1891)\end{array}$ & $\begin{array}{l}0.0599 * * \\
(2.5004)\end{array}$ & $\begin{array}{l}-0.0018 \\
(-0.0329)\end{array}$ \\
\hline$U R$ & $\begin{array}{l}-20.5629^{* * *} \\
(-13.4109)\end{array}$ & $\begin{array}{l}-6.6084^{* *} \\
(-2.3927)\end{array}$ & $\begin{array}{l}3.4359 * \\
(1.8766)\end{array}$ & $\begin{array}{c}0.0403 \\
(0.0794)\end{array}$ & $\begin{array}{l}1.7877^{* * *} \\
(3.2081)\end{array}$ & $\begin{array}{l}-0.8006^{*} \\
(-1.9613)\end{array}$ \\
\hline WS & $\begin{array}{l}-0.3344 \\
(-0.6804)\end{array}$ & $\begin{array}{l}-0.3779 \\
(-0.7786)\end{array}$ & $\begin{array}{l}-0.2781 \\
(-1.3475)\end{array}$ & $\begin{array}{c}0.1997 \\
(1.4393)\end{array}$ & $\begin{array}{c}0.0390 \\
(0.5849)\end{array}$ & $\begin{array}{c}0.0638 \\
(1.1972)\end{array}$ \\
\hline Prob. $>F$ & - & 0.0000 & 0.0000 & - & 0.0000 & 0.0000 \\
\hline Cross-section effects & - & Fixed & Fixed & - & Fixed & Fixed \\
\hline Time fixed effects & - & No & Yes & - & No & Yes \\
\hline $\begin{array}{c}\text { Panel Two-Stage Least } \\
\text { Squares }\end{array}$ & No & Yes & Yes & No & Yes & Yes \\
\hline $\begin{array}{l}\text { Panel Generalized Method } \\
\text { of Moments (GMM) }\end{array}$ & Yes & No & No & Yes & No & No \\
\hline$J$-statistic & 22.9388 & - & - & 11.6246 & - & - \\
\hline $\operatorname{Prob}(J$-statistic $)$ & 0.2400 & - & - & 0.9010 & - & - \\
\hline $\operatorname{AR}(2)$ & 0.1647 & - & - & 0.7341 & - & - \\
\hline $\begin{array}{l}\text { White period standard } \\
\text { errors \& covariance (d.f. } \\
\text { corrected) }\end{array}$ & Yes & Yes & Yes & Yes & Yes & Yes \\
\hline Breusch-Pagan-Godfrey & Yes & Yes & Yes & Yes & Yes & Yes \\
\hline $\mathrm{ARCH}$ & Yes & Yes & Yes & Yes & Yes & Yes \\
\hline $\mathrm{R}^{2}$ & 0.1194 & 0.5959 & 0.9019 & 0.8663 & 0.8837 & 0.9043 \\
\hline Adjusted $\mathrm{R}^{2}$ & 0.1012 & 0.5421 & 0.8847 & 0.8636 & 0.8683 & 0.8869 \\
\hline$F$-statistic & - & 6.5560 & 56.6245 & - & 6.7782 & 40.4529 \\
\hline Observations & 222 & 248 & 248 & 224 & 249 & 249 \\
\hline
\end{tabular}

Note: Robust $t$-statistics are indicated in parentheses. ${ }^{* * *},{ }^{* *}$ and ${ }^{*}$ show statistical significance at the $1 \%, 5 \%$, and $10 \%$ levels. Prof. $>F$ shows the probability of not existing fixed effects. The variance inflation factor (VIF) registered values below 3 , therefore indicating a low risk of multicollinearity. In addition, a battery of tests including White, Breusch-Pagan-Godfrey, and ARCH rejected the null hypothesis of heteroscedasticity. The Arellano-Bond test satisfied the validity of the instruments in the GMM estimator. Moreover, since the Hansen $J$-statistic of over-identifying restrictions was not significant $(p>0.05)$, the null hypothesis of valid instruments cannot be rejected. Therefore, the proposed models are valid.

The fourth econometric model (M4), estimated through the GMM approach, indicated that the independent variables with significant impact were GDP and HICPF, both having a positive influence on FCEH. Namely, when GDP is augmented by one unit, FCEH would follow the same trend with 1.30 units. At the same time, if HICPF improved by one unit, final consumption expenditure of households would increase by 0.69 units. 
For the fifth econometric model (M5) with no time fixed effects, $86.83 \%$ of the variance in the final consumption expenditure of households was driven by almost all predictors $(F=6.78, p<0.001)$, the majority exerting a positive influence, just as expected. For that matter, GDP had an important influence on the evolution of FCEH. Namely, if GDP rose by one-unit, final consumption expenditure would increase overall by 1.14 units. At the same time, a one-unit increase in HICPH and UR would determine a similar trend in the final consumption expenditure of households, which would increase by 0.06 units and 1.79 units, respectively.

Regarding the sixth econometric model (M6) with time fixed effects, $88.69 \%$ of the variance in the final consumption expenditure of households was driven by two predictors $(F=40.45, p<0.001)$, namely GDP and UR, with GDP having the strongest and biggest impact. Namely, if GDP rose by one-unit, final consumption expenditure would increase by 0.78 units. At the same time, a one-unit increase in $U R$ would trigger an opposite trend in FCEH, which would decrease by 0.80 units. This time, the influence of UR is less strong than the influence of GDP.

Based on the estimations of models M4-M6, it can be stated that the second research hypothesis was also supported.

With respect to the results elicited by the last three econometric models, the positive impact of HICPF and HICPH could be interpreted as follows. After price increases, individual consumers focused less on acquiring a wide variety of goods and services as they did before. Instead, consumers chose to allocate most of their budgets to basic needs such as food products (perishable or ready-made).

As expected, GDP had a positive impact on both outcome variables. A possible explanation could be the following: an increase in GDP was perceived as a slight sign of economic recovery, which ameliorated perceptions regarding the state of the national economy (i.e., economic sentiment) and it increased the level of household consumption expenditures.

\section{Discussion}

When talking about strategic and proactive thinking, the famous U.S. Army general George Patton used to say: "Prepare for the unknown by studying how others in the past have coped with the unforeseeable and the unpredictable". In today's interconnected world, changes within economic markets are often unpredictable and tend to significantly impact regular market dynamics. In this context, the aim of the present study was to determine the degree to which economic growth and inflation would significantly cause changes in economic sentiments and household consumption across countries in the European Union during the period December 2019 up to October 2020. Empirical results showed that economic sentiment within the population worsened largely because of price increases, rising inflation, and unemployment.

A sample of 28 countries within the European Union was considered in order to investigate the aforementioned relationships by means of the panel generalized method of moments and panel least squares models (with cross-section weights and time fixed effects), which were estimated with the statistical software EViews version 9.0. The Eurostat database provided the values for the variables of interest. The outcome variables were the economic sentiment indicator and the final consumption expenditure of households. The category of predictors included the following variables: gross domestic product (proxy for economic growth), harmonized index of consumer prices for perishable goods and harmonized index of consumer prices for food and beverage items catered by various industries (both regarded as proxies for inflation), wages and salaries, and total unemployment rate.

Econometric estimations confirmed the two research hypotheses stemming from prior empirical research: economic sentiment and household consumption were significantly influenced by the selected proxies of economic growth and inflation. Moreover, in the case of economic sentiment, the results indicated that the negative impact of inflation was much 
stronger than the positive impact of economic growth. The reverse was applicable in the case of household consumption.

Starting from the empirical results of this study, relevant policy implications can be drawn. In challenging periods when national economies are perceived to be deteriorating and consumer behavior registers downward trends, in order to counterbalance the effects of such trends, governments and companies should aim at stimulating consumption through different sustainable means while controlling for inflation (Batrancea et al. 2019, 2020). The explanation is straightforward: During a crisis, uncertainty drives people to focus on savings and, as a consequence, the overall consumption level drops significantly. In this regard, some governments may deploy cash into national economies to support taxpayers or aim to do this. For instance, public authorities in the United Kingdom introduced the so-called "Eat out to help out" 2 scheme throughout August 2020 to support businesses in the hospitality sector. They subsidized half of the cost for meals taken on the premises of hospitality establishments (i.e., maximum $£ 10$ /customer for food and/or non-alcoholic drinks). The scheme included 78,116 companies and a capital infusion of $£ 840$ million, exceeding the forecasted amount of $£ 500$ million. Across the ocean, the US go-vernment has enacted a "stimulus and relief package" of $\$ 1.9$ trillion to alleviate the challenges of the federal economy ${ }^{3}$. Along the same line, the European Union has created a $€ 750$ million temporary fund for the same purpose, which constitutes the largest stimulus fund allocated so far by the $\mathrm{EU}^{4}$.

Moreover, in times of crises, many businesses tend to show tremendous resilience, and managers put all their efforts in finding solutions to overcome economic adversities and improve economic sentiment. For instance, because of the COVID pandemic, the unforeseen global slump has uncovered a noteworthy behavior, especially on behalf of fa-mily business in the word and in Europe, where these types of companies represent around $65-80 \%$ of overall businesses. According to a recent PricewaterhouseCoopers (2021), $25 \%$ of the surveyed family business owners and managers refocused their manufacturing activities in order to meet consumers' needs generated by this health crisis (e.g., medical equipment and medical devices such as masks, gloves, visors, gowns, hand sa-nitizers, disinfectant products). Other family businesses and non-family companies have completely changed their business strategy from operating exclusively onsite to going online in an attempt to maintain their loyal customer network (where applicable).

At the other end of the spectrum, consumers may also play an important part in this equation. For instance, one strategy of incentivizing consumers to support their local communities while navigating an economic crisis is the use of "buy local" nudging messages, derived from the nudge theory (Thaler and Sunstein 2008). Richard Thaler, one of the architects of this theory that alters choice architecture and the 2017 Nobel Laureate in Economics, stated in his famous book: "The bottom line is that humans are easily nudged by other humans. Why? One reason is that we like to conform. Doing what others do". Consequently, such clear and simple messages of "buy local" displayed on business premises, social media websites, and mass-media may steer many consumers towards redirecting their basic needs toward local brands and companies, which can be rather neglected in favor of more popular or world-famous retailers.

This study has certain limitations. In the first place, the sample included only 28 countries from the European Union. Future studies might consider increasing the sample with other European nations and countries from different continents in order to test the robustness of the relationships. For that matter, comparisons between clusters of nations from various continents could also be considered. Second, since the period of analysis focused on 11 months, the time frame could also be expanded. Third, since economic sentiments and household consumption are complex phenomena, whose variance is also determined by other predictors besides the ones considered in this manuscript, upcoming research could explore the impact of such variables.

All in all, economic contexts with high uncertainty levels can be associated with real stress tests suddenly applied to the overly-connected world economy, thus unveiling inter- 
esting results. When economic sentiments worsen and household consumption patterns decline substantially, authorities are called to stimulate national economies by designing efficient policies. In addition, companies should also aim at incentivizing regular clients to continue purchasing their goods and services, while making efforts to expand their customer network.

Funding: This research received no external funding.

Institutional Review Board Statement: Not applicable.

Informed Consent Statement: Not applicable.

Data Availability Statement: Data sharing not applicable.

Conflicts of Interest: The author declares no conflict of interest.

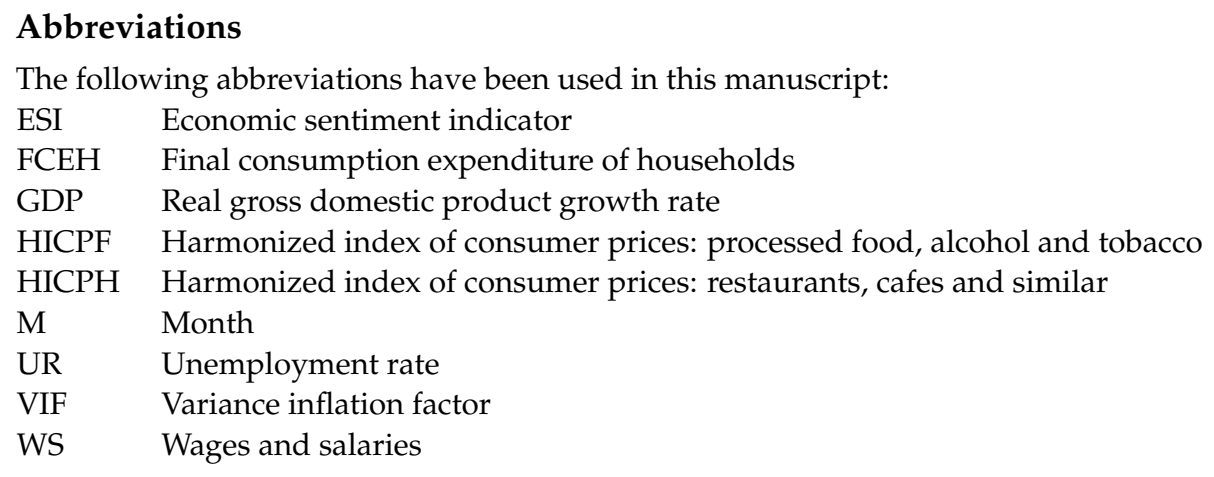

\section{Notes}

1 https://www.mq15.com/en/economic-calendar/european-union/economic-sentiment-indicator (accessed on 20 January 2021).

2 https://commonslibrary.parliament.uk/research-briefings/cbp-8978/ (accessed on 20 March 2021).

3 https://www.wsj.com/articles/house-set-to-approve-covid-19-relief-bill-11615372203 (accessed on 12 March 2021).

4 https://ec.europa.eu/info/strategy/recovery-plan-europe_en (accessed on 10 March 2021).

\section{References}

Aggarwal, Divya. 2019. Defining and measuring market sentiments: A review of the literature. Qualitative Research in Financial Markets. [CrossRef]

Aguilar, Pablo, Corinna Ghirelli, Matías Pacce, and Alberto Urtasun. 2021. Can news help measure economic sentiment? An application in COVID-19 times. Economics Letters 199: 109730. [CrossRef]

Ahmed, Walid M. A. 2020. Stock market reactions to domestic sentiment: Panel CS-ARDL evidence. Research in International Business and Finance 54: 101240. [CrossRef]

Ariely, Dan. 2010a. Predictably Irrational: The Hidden Forces that Shape Our Decisions, revised and expanded ed. New York: HarperCollins. Ariely, Dan. 2010b. The Upside of Irrationality: The Unexpected Benefits of Defying Logic at Work and at Home. New York: HarperCollins.

Ariely, Dan. 2016. Payoff: The Hidden Logic that Shapes Our Motivations. New York: Simon \& Shuster.

Ariely, Dan, and Jeff Kreisler. 2017. Dollars and Sense: How We Misthink Money and How to Spend Smarter. New York: HarperCollins.

Baddeley, Michelle. 2017. Behavioural Economics: A Very Short Introduction. Oxford: Oxford University Press.

Baker, Malcom, and Jeffrey Wurgler. 2006. Investor sentiment and the cross-section of stock returns. Journal of Finance 61: 1645-80. [CrossRef]

Baker, Malcom, and Jeffrey Wurgler. 2007. Investor sentiment in the stock market. Journal of Economic Perspectives 21: 129-52. [CrossRef]

Baker, Malcom, Jeffrey Wurgler, and Yu Yuan. 2012. Global, local, and contagious investor sentiment. Journal of Financial Economics 103: 272-87. [CrossRef]

Bammer, Gabriele, and Michael Smithson, eds. 2009. Uncertainty and Risk: Multidisciplinary Perspectives, 1st ed. Abingdon: Routledge. Batrancea, Ioan, Larissa Batrancea, Anca Nichita, Lucian Gaban, Ema Masca, Ioan-Dan Morar, Gheorghe Fatacean, and Andrei Moscviciov. 2019. An econometric approach on production, costs and profit in Romanian coal mining enterprises. Economic Research-Ekonomska Istraživanja 32: 1019-36. [CrossRef]

Batrancea, Larissa, Malar Maran Rathnaswamy, Ioan Batrancea, Anca Nichita, Mircea-Iosif Rus, Horia Tulai, Gheorghe Fatacean, Ema Speranta Masca, and Ioan Dan Morar. 2020. Adjusted net savings of CEE and Baltic nations in the context of sustainable economic growth: A panel data analysis. Journal of Risk and Financial Management 13: 234. [CrossRef] 
Batrancea, Larissa, and Anca Nichita. 2015. Which is the best government? Colligating tax compliance and citizens' insights regarding authorities' actions. Transylvanian Review of Administrative Sciences 44E: 5-22.

Batrancea, Larissa, Anca Nichita, Ioan Batrancea, Ana Maria Roux Valentini Coelho Cesar, and Denis Forte. 2018. Sustainable tax behavior on future and current emerging markets: The case of Romania and Brazil. In Sustainability and Social Responsibility of Accountability Reporting System: A Global Approach. Edited by Kiymet T. Çaliyurt and Roshima Said. Singapore: Springer, pp. 141-58.

Chen, Haiqiang, Terence Tai-Leung Chong, and Xin Duan. 2010. A principal component approach to measuring investor sentiment in China. Quantitative Finance 10: 339-47. [CrossRef]

Corr, Philip, and Anke Plagnol. 2018. Behavioral Economics: The Basics. New York: Routledge.

Çepni, Oğuzhan, I. Ethem Guney, Rangan Gupta, and Mark E. Wohar. 2020. The role of an aligned investor sentiment index in predicting bond risk premia of the U.S. Journal of Financial Markets 51: 100541. [CrossRef]

Dalika, Naeem, and Yudhvir Seetharam. 2015. Sentiment and returns: An analysis of investor sentiment in the South African market. Investment Management and Financial Innovations 12: 267-76.

Economist Intelligence Unit. 2018. Cause for Concern? The Top 10 Risks to the Global Economy. New York: Economist Intelligence Unit.

Funston, Frederick, and Stephen Wagner. 2010. Surviving and Thriving in Uncertainty: Creating the Risk Intelligent Enterprise. Hoboken: John Wiley \& Sons.

Haritha, P. H., and Abdul Rishad. 2020. An empirical examination of investor sentiment and stock market volatility: Evidence from India. Financial Innovation 6: 34. [CrossRef]

Huang, Dashan, Fuwei Jiang, Jun Tu, and Guofu Zhou. 2015. Investor sentiment aligned: A powerful predictor of stock returns. Review of Financial Studies 28: 791-837. [CrossRef]

Kahneman, Daniel. 2012. Thinking, Fast and Slow, 1st ed. London: Penguin Books.

Kahneman, Daniel, and Amos Tversky. 1979. Prospect theory: An analysis of decision under risk. Econometrica 47: 263-92. [CrossRef]

Kitrar, Liudila, and Tamara Lipkind. 2020. Analysis of the relationship between the economic sentiment indicator and GDP growth. Ekonomicheskaya Politika 15: 8-41. [CrossRef]

Köhn, Julia. 2017. Uncertainty in Economics: A New Approach, 1st ed. Berlin: Springer.

Milani, Fabio. 2017. Sentiment and the U.S. business cycle. Journal of Economic Dynamics and Control 82: 289-311. [CrossRef]

Nichita, Anca, Larissa Batrancea, Ciprian Marcel Pop, Ioan Batrancea, Ioan Dan Morar, Ema Masca, Ana Maria Roux-Cesar, Denis Forte, Henrique Formigoni, and Adilson Aderito da Silva. 2019. We learn not for school but for life: Empirical evidence of the impact of tax literacy on tax compliance. Eastern European Economics 57: 397-429. [CrossRef]

Nogueira Reis, Pedro Manuel, and Carlos Pinho. 2020. A reappraisal of the causal relationship between sentiment proxies and stock returns. Journal of Behavioral Finance. [CrossRef]

Nowzohour, Laura, and Livio Stracca. 2020. More than a feeling: Confidence, uncertainty, and macroeconomic fluctuations. Journal of Economic Surveys 34: 691-726. [CrossRef]

Pandey, Piyush, and Sanjay Sehgal. 2019. Investor sentiment and its role in asset pricing: An empirical study for India. IIMB Management Review 3: 127-44. [CrossRef]

PricewaterhouseCoopers. 2021. From Trust to Impact: Why Family Businesses Need to Act Now to Ensure Their Legacy Tomorrow. Berlin: PwC.

Rakovská, Zuzana. 2021. Composite survey sentiment as a predictor of future market returns: Evidence for German equity indices. International Review of Economics E Finance 73: 473-95. [CrossRef]

Ruan, Qingsong, Zilin Wang, Yaping Zhou, and Dayong Lv. 2020. A new investor sentiment indicator (ISI) based on artificial intelligence: A powerful return predictor in China. Economic Modelling 88: 47-58. [CrossRef]

Sibley, Steven E., Yanchu Wang, Yuhang Xing, and Xiaoyan Zhang. 2016. The information content of the sentiment index. Journal of Banking \& Finance 62: 164-79. [CrossRef]

Sun, Yunpeng, Qun Bao, and Zhou Lu. 2021. Coronavirus (Covid-19) outbreak, investor sentiment, and medical portfolio: Evidence from China, Hong Kong, Korea, Japan, and U.S. Pacific-Basin Finance Journal 65: 101463. [CrossRef]

Swamy, Vighneswara. 2020. Financial wealth effects and consumption expenditure. International Journal of Finance E Economics. [CrossRef]

Telega, Ivan, and Agnieszka Telega. 2020. Driving factors of material consumption in European countries-spatial panel data analysis. Journal of Environmental Economics and Policy 9: 269-80. [CrossRef]

Thaler, Richard H. 2016. Misbehaving: The Making of Behavioural Economics. London: Penguin Books.

Thaler, Richard H., and Cass R. Sunstein. 2008. Nudge: Improving Decisions about Health, Wealth and Happiness. New Haven: Yale University Press.

Van der Wielen, Wouter, and Salvador Barrios. 2020. Economic sentiment during the COVID pandemic: Evidence from search behaviour in the EU. Journal of Economics and Business 115: 105970. [CrossRef]

Van Giesen, Roxanne I., and Rik Pieters. 2019. Climbing out of an economic crisis: A cycle of consumer sentiment and personal stress. Journal of Economic Psychology 70: 109-24. [CrossRef]

Wakker, Peter P. 2010. Prospect Theory: For Risk and Ambiguity. New York: Cambridge University Press.

Yang, Wen, Dongtong Lin, and Zelong Yi. 2017. Impacts of the mass media effect on investor sentiment. Finance Research Letters 22: 1-4. [CrossRef] 
Zanin, Luca. 2010. The relationship between changes in the economic sentiment indicator and real GDP growth: A time-varying coefficient approach. Economics Bulletin 30: 837-46.

Zaremba, Adam, Adam Szyszka, Huaigang Long, and Dariusz Zawadka. 2020. Business sentiment and the cross-section of global equity returns. Pacific-Basin Finance Journal 61: 101329. [CrossRef] 